\title{
Platónův dialog Lysis a přátelství v Etice Nikomachově
}

\section{Josef Moural}

Knihy VIII a IX Etiky Níkomachovy, věnované přátelství (filia), stojí do jisté míry stranou zájmu badatelů. Je to nejspíš proto, že to vypadá, jako by do celku díla vlastně nepatřily: nejde ani tak o to, že téma, vytyčené v knize I, již bylo dovedeno k závěru v knihách VI a VII, jako především o to, že pojem prátelství nespadá do oblasti jednání (jak je rozvržena mj. v $O$ duši III 10). ${ }^{\text {i }}$ Pochybnosti, zda se tyto knihy v textu neocitly nějakým nedopatřením, však nikdy nebyly opravdu silné: o prátelství máme paralelní úsek i v Eudémově etice a studium přátelství hraje důležitou roli $\mathrm{v}$ přechodu mezi etikou a politikou, jelikož přátelství Aristotelovi slouží jako model pro zdárné vztahy $\mathrm{v}$ politickém společenství. ${ }^{\text {ii }}$

Tématem mého př́spěvku není problematika přátelství $\mathrm{v}$ Níkomachově etice $\mathrm{v}$ celé své šiři ${ }^{\mathrm{iii}}$ nýbrž pouze srovnání Aristotelova výkladu s Platónovým dialogem Lysis. Tematické blízkosti pasáže 1155a32-b12 v Aristotelově

\footnotetext{
i $\quad$ Sparshott 1994, s. 264 a 271.

ii Scorza 2004, s. 85.

iii Dobrý přehled skýtají např. Cooper 1980 či Whiting 2006.
} 
výkladu s pasáží 213d6-215c2 v dialogu Lysis si mnozí badatelé povšimli, ${ }^{i}$ zatím však nebyla zevrubněji zkoumána. zkoumána. Pokusím se nově ukázat, že ústřední teze knihy VIII Níkomachovy etiky, totiž že prátelství je několik druhů, mezi nimiž je třeba rozlišovat (NE 1156a7) navazuje přirozeně na ústřední myšlenku dialogu Lysis.

1.

Nejnápadnější obdoby se týkají pasáže na počátku osmé knihy Etiky Níkomachovy, v níž Aristotelés probírá několik nejasností, jež lze najít v obíhajících míněních o prátelství. Podívejme se na následující třii (kde to je vhodné, uvádím i paralelní pasáž z Etiky Eudémovy; citáty v češtině se opírají o překlady Antonína Kříže a Františka Novotného).

(i) jsou si práteli podobní nebo naopak?

Aristotelés:

„Jedni je <tj. prátelství - J.M.> pokládají za jakousi podobnost a přátele za sobě podobné, proto prý se rríká »rovný rovného si hledá« a »vrána $\mathrm{k}$ vráně sedá«, a podobně. Druzí zase naopak ř́kají, že všichni takoví se $\mathrm{k}$

\footnotetext{
Např. Penner, Rowe 2005, s. 317; Whiting 2006, s. 279; Burger 2008, s. $269-270$.
} 
sobě chovají jako hrnčír $\mathrm{k}$ hrnčíríi ${ }^{\mathrm{i}}$. A vysvětlení pro to hledají hlouběji, i ve zjevech prrírodních; tak Euripidés praví, že vypráhlá půda miluje déšt' [...]. Naopak zase jiní se vyjadřují jinak, zvláště Empedoklés praví, že podobné směřuje k podobnému.“ (NE 1155a32-b7)

„Někteří totiž mají za to, že podobný je př́telem podobnému; odtud se říká »bůh vždy rovného k rovnému vede «ii, »vrána $\mathrm{k}$ vráně« a »rozpozná zloděj zloděje a vlk vlka«. A fyziologové dokonce shledávají v celku př́rody řád založený na principu, že podobné jde $\mathrm{k}$ podobnému, následkem čehož Empedoklés řekl, že pes sedá na dlaždičce, protože je mu nejpodobnější. Někteří tedy podávají takový výklad; jiní zase říkají, že opak je přátelský opaku. Nebot' prátelské (filon) je všude to, co je milováno a co je předmětem touhy, a suché netouží po suchém, nýbrž po vláze (proto se říká »země miluje déšt'« a »změna je vždycky sladká« - tj. změna v něco opačného). Naopak podobné nesnáší podobné, nebot' "na hrnčíře nevraží hrnčíř« a zviřata, živící se ze stejných zdrojů, bojují spolu navzájem. ...“(

i Hrnčíři jakožto přísloveční představitelé navzájem na sebe nevražících konkurentů tu snad odkazují na Hésioda, Práce a dny 25 („Hrnčíři sokem je hrnčíř a tesaři bývá jím tesař / žebráku závidí žebrák a žárlí na pěvce pěvec“, překlad A. Salače); pasáž je citována již v dialogu Lysis, 215c8-9.

ii Homér, Odysseia XVII 218 (překlad O. Vaňorného); pasáž citována již v dialogu Lysis, 214a6. 


\section{A Platón:}

„To vyjadřují < básníci - J.M.> asi takto: »nebot' zajisté bůh vždy rovného k rovnému vede« a s ním ho seznamuje; či jsi nepřišel na tento verš?

Zajisté.

To jsi bezpochyby přišel i na spisy velmi moudrých mužů, kteří tvrdí totéž, že podobné je vždy nutně přátelské podobnému? To jsou asi ti, kteří rozmlouvají a píší o přírodě a o vesmíru.“ (Lys. 214a5-b5)

„A přece $\mathrm{v}$ tom cítím jakousi obtíž [...]. Je podobný přítelem podobnému na základě té podobnosti a je takový takovému užitečný?"“ (Lys. 214e3-5)

„Již jsem kdysi slyšel někoho tvrdit a právě si na to vzpomínám, že prý podobné podobnému [...] jsou největšími nepřáteli; ano také uváděl za svědka slova Hésiodova, že »na hrnčíře nevraží hrnčír a na pěvce pěvec / na žebráka zas žebrák«, a takto prý i všude jinde věci nejpodobnější se nejvíce naplňují vzájemnou závistí, řevnivostí a neprátelstvím, kdežto věci nejnepodobnější prátelstvím: chud’as je prý totiž nucen být přítelem boháči, slabý silnému, aby od něho dostal pomoc, nemocný lékaři a každý nevědoucí prý má zálibu ve vědoucím a miluje ho.“ (Lys. 215c4-d7) 
Je zřejmé, že všechny tři texty se shodují v řadě rysů. Jde v nich o zachycení obíhajících názorů (u některých je dokonce udán pramen), nikoli o vlastní myšlenkovou práci. Dochází v nich k mísení prííkladů z lidského soužití (Homér versus Hésiodos) a $\mathrm{z}$ prírodních dějů (Empedoklés versus Euripidés), a výběr prríkladů se $\mathrm{z}$ velké části shoduje. Ve všech konečně je vzájemná neslučitelnost hromaděných tezí průběžně registrována (resp. u Aristotela je snad i principem jejich hromadění) a je něčím, $\mathrm{k}$ čemu má myslitel hromadící tyto neslučitelné názory následně zaujmout postoj.

V dialogu Lysis bude tímto postojem (přinejmenším pro př́slušnou chvíli) odmítnutí obou možností: „Tedy ani podobné s podobným ani opačné s opačným nejsou přáteli.“ (Lys. 216b8-9) U Aristotela nacházíme naopak diferenciaci pojmu prátelství jak na tři různé druhy ( $N E$ 1156a7, $E E$ 1236a31), tak na různé další možnosti v rámci každého druhu, což mu pak dovolí najít takové podoby přátelství, u nichž je typický přátelský vztah podobného k podobnému (přátelství založené na ctnosti, areté) nebo opačného $\mathrm{k}$ opačnému (přátelství založené na užitečnosti).

(ii) mohou si špatní být přáteli, nebo jen dobř́? Aristotelés: 
„uvažujme o tom, [...] zda přátelství vzniká u všech lidí, anebo je-li nemožné, aby lidé špatní (mochthéroi) byli práteli““ (NE 1155b10-12)

„Někteří totiž mají za to, že není možné, aby špatní (fauloi) byli práteli, nýbrž jedině dobří ...“( $E E$ 1235a31-33)

\section{A Platón:}

„čím blíže prrichází špatný (ponéros) k špatnému a čím více se s ním stýká, tím větším nepř́itelem se mu stává. Nebot' se dopouští křivd; avšak je asi nemožno, aby ti, kdo křivdí, a ti, kterým se křivdí, si byli přáteli.“ (Lys. 214b8-c3)

„př́itelem je jedině dobrý dobrému, avšak zlý (kakos) nikdy nevstupuje do opravdového přátelství ani s dobrým ani se zlým“ (Lys. 214d5-7)

Oba autoři obměňují slovní označení špatných či zlých, ti jsou nicméně ve všech uvedených kontextech protikladem dobrých (agathoi), a v rámci této studie nebudu otvírat otázku, jakou mohou posuny označení mít funkci. U obou autorů je dále $\mathrm{v}$ tomto př́ípadě už méně jasné, zda jde opět jen o zachycení obíhajících názorů, nebo zda se zde již dostáváme do jejich vlastního myšlenkového světa: pouze $\mathrm{v}$ Eudémově etice jde jednoznačně o pokračování výčtu aporií (1235a4) či mínění (doxai - 1235a30). V Nikomachově etice je již pasáž uvozena slovem ,uvažujme o tom“ (taut' 
episkepsómetha - 1155b10), a navazuje na ni plynule již pasáž obsahující počátek Aristotelova vlastního výkladu. A v dialogu Lysis argument i jeho závěr Sókratés uvádí jako vlastní myšlenku (nebo přinejmenším takovou, o níž v kontextu $\mathrm{s}$ hustým výskytem myšlenek deklarovaně přejatých neuvádí, že by byla přejatá).

U Aristotela bude řešením nejasnosti opět diferenciace pojmu přátelství, která poskytne místo pro obě možnosti: $\mathrm{s}$ ohledem na užitek a rozkoš si mohou být práteli i špatní (i když jejich přátelství bude i $\mathrm{v}$ těchto oblastech nedokonalé a riskantní), s ohledem na ctnost nikoli (1157a16-20). U Platóna dochází k opuštění epizodického závěru, že dobří jsou přáteli dobrým, na základě úvahy (tentokrát uvedené Sókratem jako jeho vlastní), že by si nebyli k užitku, nebot' (a) by si byli př́iliš podobní (a suché touží po vláze atd. 214e3-5, 215e3-216a1), a (b) jakožto dobří by byli soběstační a nic by tedy nepotřebovali (215a6-c2).

(iii) může být prátelství s neživými věcmi?

Aristotelés:

„nemluví se o prátelství při lásce $\mathrm{k}$ věcem neživým (apsycha). Nebot' tu není vzájemné lásky, ani chtění jejich dobra - vždyt' by bylo směšné chtít, aby se víno mělo dobře, leda chce-li někdo, aby se uchovalo, aby sám měl 
dobré víno -; příteli však, jak se říká, máme přát dobro pro něho." (NE 1155b27-31)

Platón:

„Tedy nejsou ani přátelé koní, když jich koně navzájem nemilují, ani přátelé křepelek, ani zase přátelé psů a vína a tělocviku ...“( Lys. 212d5-7)

Pasáž z Etiky Níkomachovy je z té části textu, kde Aristotelés již nehromadí cizí mínění, nýbrž argumentuje sám za sebe (a podává zde dosti príijatelné řešení nejasnosti, kterou zanechal Platón). Naopak pasáž z dialogu Lysis je součástí argumentace, která nejspíš není míněna docela vážně, a pozice v ní zastávaná bude diskutujícími v dialogu dialogu záhy opuštěna (212e5-213a5).

Daly by se najít snad i další textové paralely, ukazuje se na nich na všech ale v zásadě totéž: Aristotelés nechává dialog Lysis spoluurčit výchozí problematiku svého pojednání prátelství v obou Etikách. Dosud uvažované paralely mají nezanedbatelný rozsah, ale obsahově nejsou hluboké. U obou myslitelů mají texty z uvedených paralel bud' status něčeho, co se jen ř́íká (a náš úkol je to vysvětlit), nebo (u Platóna) status myšlenek, u nichž sice není deklarováno, že by pocházely $\mathrm{z}$ běžné řeči, ale jsou uváděny jako

i O tom více v mém starším článku (Moural 2004). 
epizodická, průchozí stádia rozmluvy. Možnost, že by tu nešlo o vztah Aristotelés-Platón, nýbrž že by oba čerpali ze společného a nám neznámého zdroje (nemíním tu obíhající řeči, ale jejich autorské shromáždění), pochopitelně nejde vyloučit (a Aristotelés tu žádný z nahromaděných názorů nepřipisuje Platónovi ani Sókratovi), ale není považována za nijak pravděpodobnou.

2.

Již bylo řečeno, že Aristotelés ve svých Etikách podává systematickou diferenciaci pojmu prátelství, díky níž se ony povrchní potíže, pocházející z nerozlišování mezi různými podobami přátelství, vesměs samy rozplynou. Přátelství jsou tři druhy (eidé): (i) pro užitek, (ii) pro rozkoš a (iii) mezi dobrými a v ctnosti si podobnými. Přátelství mohou být symetrická i asymetrická (nerovnocenná), jako např. mezi rodiči a dětmi, mužem a ženou, nadřízeným a podřízeným, atd. Podle převažujícího typu přátelství se dokonce rozlišují základní možná politická zř́zení (NE VIII 12-13).

To je zajisté významný pokrok ve srovnání s Platónovým pojednáním. Bylo by lze ovšem poukazovat na to, že některá $\mathrm{z}$ rozlišení byla $\mathrm{v}$ dialogu Lysis již předznačena: 
ukázalo se tam zejména, jak se promění úvahy o přátelství, když na ně pohlížíme z hlediska jeho užitečnosti (214e216a). Ale krok k diferenciaci pojmu přátelství, jež by odstranila konfúze a řešila zdánlivé nejasnosti, u Platóna učiněn není. Nebo přece?

Je-li zdařilá má interpretace dialogu Lysis (Moural 2004), pak i přesto, že krok směrem $\mathrm{k}$ diferenciaci pojmu přátelství není v dialogu výslovně vykonán, je potřeba této diferenciace jeho ústředním tématem. Nemohu zde opakovat argumentaci ze staršího článku; shrnu zde jen docela stručně, že poté, co je Sókratés uvolněn z obou úkolů, k jejichž plnění se v první polovině dialogu postupně zaváže, začne oba chlapce učit prvním dovednostem filosofického řemesla - nebo snad jen jediné (jednoduché, ale důležité): umění distinkce. A materiálem, na němž si chlapci mají tento krok vyzkoušet a tak si onu dovednost začít osvojovat, jsou právě problémy, týkající se přátelství.

Je-li tomu vskutku tak, pak můžeme vidět mezi dialogem Lysis a Aristotelovými Etikami spojitost, která je daleko hlubší než jen výpůjčky $\mathrm{v}$ citátech a jiných formulacích obíhajících názorů. Co je u Platóna materiálem pro vzdělávací hru (i když snad nikterak nahodile zvoleným), to je u Aristotela systematicky vypracováno a zapojeno do 
ambiciózní konstrukce, v níž jsou spojeny etika a politika. Ale, mohli bychom říci, Aristotelés vposledku jen vykonává to, k čemu ho Sókratés z dialogu Lysis vybízí, a dává nám prríklad žáka, který zadanou úlohu bystře chápe a tvořivě plní a který to (pokud víme) dotáhl ve filosofii o hodně dál než jeho předchůdci, Lysis a Menexenos. ${ }^{\mathrm{i}}$

i Je št'astnou okolností, že tuto studii mohu věnovat památce doc. Milana Mráze, školitele své vědecké aspirantury. Plaché přátelství, které se mezi námi rozvinulo, mělo na mé straně svůj počátek a cíl v užitku (dosažení hodnosti kandidáta věd). Věřím, že oběma stranám skýtalo čas od času i přiměřené potěšení, a rád bych doufal, že mu nechyběla ani dimenze přátelství mezi lidmi dobrými a v ctnosti si podobnými. O míře nerovnosti, která je především zpočátku provázela, jsem následkem Mrázovy pověstné skromnosti dlouho neměl ani tušení. 


\section{AIOHP III.5}

\section{BIBLIOGRAFIE:}

Burger, R., 2008, Aristotle's Dialogue with Socrates: On the Nicomachean Ethics, Chicago.

Cooper, J. M., 1980, „Aristotle on Friendship“, in: Rorty, A. O. (ed.), Essays on Aristotle's Ethics, Berkeley, s. 301-340.

Moural, J., 2004, „Sókratova činnost v dialogu Lysis“, in: Havlíček, A. (ed.), Platónův dialog Lysis, Praha, s. 182-223.

Penner, T., Rowe, Ch., 2005, Plato's Lysis, Cambridge.

Scorza, J. A., 2004, „Liberal Citizenship and Civic Friendship“, Political Theory 32, s. 85-108.

Sparshott, F., 1994, Taking Life Seriously: A Study of the Argument of the Nicomachean Ethics, Toronto.

Whiting, J., 2006, „The Nicomachean Account of Philia“, in: Kraut, R. (ed.), The Blackwell Guide to Aristotle's Nicomachean Ethics, Oxford, s. 276-304. 